\title{
Fish Based Fortified Foods- A Glimpse Towards Future Potential
}

\author{
Niladri Chakraborty and Asit K Saha* \\ Department of Food Technology, Haldia Institute of Technology, India
}

\section{INTRODUCTION}

Fish is an important source of good quality protein and lipid contents for most parts of the world. It is considered as an excellent supplementary food item to meet the requirements of essential amino acids (particularly lysine) for us. It also contains good lipids (such as triglycerides, phospholipids, cholesterol and cholesteryl esters) and fat-soluble vitamins (A, D and E) either in small or large percentage (in cod, halibut and shark). Fish contains SFA (saturated fatty acids), MUFA (monounsaturated fatty acids), PUFA (polyunsaturated fatty acids), EPA ( $\omega-3$ eicosapentaenoic acid), DHA ( $\omega-3$ decosahexaenoic acid) and $\omega-6$ arachidonic acid. So, to avoid coronary disease among men it has been recommended to have the intake in the diet at least 2 to 3 serving times per week [1]. The presence of TMAO (trimethylamine oxide), high content of NPN (non-protein nitrogen), variable lipid content with high degree of unsaturation and high amount of $\omega-3$ fatty acids, low carbohydrate content with high $\mathrm{pH}(=6)$, termed as "low-acid food" (as $\mathrm{pH} \geq 4.5$ ). The combined total amount of ammonia, TMA and DMA is called total volatile base nitrogen (TVBN). The freshness of fish is identified by TVBN, since it is an indicator of fish detoriation [2] and also the detection of mercury (Hg) is essential for final fish products. Present work aims to prepare fortified foods which contain different macro and micronutrients in one product easily at a competitive cost. To get the desired nutrients, successive blending of sterilized fishes with aloe vera and kiwi fruit pulp was performed followed by adding flours proportionately to reduce moisture load for vacuum drying and hence the process cost.

\section{MATERIALS AND METHODS}

Fishes [Catla (Catla Catla), Chela (Chela Cachius)] and Shrimp (Metapenaeus Monoceros) [let abbreviated as CC, $\mathrm{CH}$ and SP respectively] were selected for present study since they are important food stuffs to provide a rich source of animal protein, essential micronutrients, essential $\omega-3$ PUFA and minerals. CC is a tasty fish and enriched with high nutritional value [3]. Seasonal fish chela is found in tropical countries only during monsoon. $\mathrm{CH}$ has high energy value (350 kJ per $100 \mathrm{~g}$ ) and very rich in $\mathrm{Zn}$ (4.7 mg per $100 \mathrm{~g})$, Ca (1g per $100 \mathrm{~g}), \mathrm{P}$ (590 mg per 100g), Mn (0.6 mg / $100 \mathrm{~g}$ ), $\mathrm{S}$ (170 mg / $100 \mathrm{~g})$, vitamins (A, D and B12) [4,5].

Hence, $\mathrm{CH}$, if preserved, can be utilized to develop novel foodstuffs following suitable protocol depending upon the regional needs. SP is costly, high energy content and rich in $\mathrm{Fe}, \mathrm{Ca}, \mathrm{I}, \mathrm{Se}, \mathrm{P}, \mathrm{Mg}$, $\mathrm{Na}, \mathrm{Mn}, \mathrm{K}, \mathrm{Cu}, \mathrm{S}$, pigments (astaxanthin and astacin) and vitamin $\mathrm{E}$ as well [5].

Fishes and Shrimp (CC, CH, and SP) were step-wisely cooked by sterilization (at $121{ }^{\circ} \mathrm{C}$ for 15 minutes) and blended (with a speed about 400-500 rpm for 20-30 s) taking them in 1:1:1 ratio to make a paste. Then corn flour (CF) $10 \%(\mathrm{w} / \mathrm{w})$, rice flour (RF) $2 \%(\mathrm{w} / \mathrm{w})$, and pulp-juice [aloe vera pulp (Aloe barbadensis): kiwi (Actinidia deliciosa) juice :: 1 : 1; let abbreviated as APKJ), 50\% (v/w) was added with sterilized and pre-blended fishes by specific blending methodology (same speed for 30-40 s).

The added substances (CF, RF, and APKJ) were selected on the basis of their availability and nutritional gain, to improve texture and also to increase the shelf life [6]. Finally vacuum-drying, VD, (vacuum pressure $5 \times 10^{-1} \mathrm{mbar}$ and condenser temperature $-40^{\circ} \mathrm{C}$ ) was applied for blended material, crushed to powder by grinder and put into an airtight container for storing. The heat / enthalpy of evaporation in vacuum-drying of processed fish were supplied by silver plate heater $(220 \mathrm{~V}, 166 \mathrm{~mA}$, and $36 \mathrm{~W})$ as described elsewhere [12].

\begin{tabular}{|l|l|} 
Quick Response Code: & $\begin{array}{l}\text { Address for correspondence: Asit K Saha, Principal, Haldia Institute of Technology, } \\
\text { India }\end{array}$ \\
\cline { 2 - 3 } & $\begin{array}{l}\text { Received: July 07, } 2020 \quad \text { Published: July 22, } 2020 \\
\text { How to cite this article: Chakraborty N, Saha A.K. Fish Based Fortified Foods- A Glimpse } \\
\text { Towards Future Potential. } 2020 \text { - 2(4) OAJBS.ID.000195. DOI: } 10.38125 / O A J B S .000195\end{array}$ \\
\end{tabular}


A resistance temperature device (RTD) was inserted into the blended material (kept on Ag-plate, depth or thickness of sample $0.002 \mathrm{~m}$ )) for the observation of VD sample's temperature. Another RTD was used for measuring the temperature of the Ag-plate and it related to temperature controller (PID). The plate temperature was set at $55^{\circ} \mathrm{C}$ (accuracy $\pm 2{ }^{\circ} \mathrm{C}$ ). During VD, weight of sample was recorded at fixed time interval. The VD time was also recorded till the final moisture content of the sample became $\leq 5 \%(\mathrm{w} / \mathrm{w})$.

The drying kinetics was studied by different models (Newton, Page, Henderson \& Pebis, Modified Page, Linear, Wang \& Singh, Modified Wang \& Singh models). The effective diffusivities $\left(\mathrm{D}_{\text {eff }}\right)$ and activation energy (E) were measured during drying at three considered temperatures $\left(40{ }^{\circ} \mathrm{C}, 45^{\circ} \mathrm{C}\right.$, and $\left.50{ }^{\circ} \mathrm{C}\right)$. The quality of dried products has been measured and analyzed.

The moisture percentage, pH, water activity (aw), total carbohydrate, protein, total fat, energy, total ash, total volatile base nitrogen (TVBN), histamine and Omega-3 ( $\omega-3)$ fatty acid, mercury level of the VD product was measured using standard methods (Table 1). Also, sensory analysis (done by 22 testers) was performed by hedonic scale6 for final VD samples (scores of sensory characteristics: appearance, color, flavor, taste, texture and overall acceptability).

Table 1: Quality analysis of final blended and vacuum-dried product.

\begin{tabular}{|c|c|c|c|}
\hline Quality Parameters & Final VD Product & Test Method & Reference(s) \\
\hline Total Carbohydrate (g/100g) & 34.99 & $\begin{array}{l}\text { (2012) AOAC Official Methods. } 19^{\text {th }} \\
\text { Edn, Vol- II, } 986.25\end{array}$ & Fssai [7]; Maskan [8] \\
\hline Protein $(\mathrm{g} / 100 \mathrm{~g})$ & 50.66 & IS:7219-1973 (Rffm -2010) & Chakraborty et al. [9] \\
\hline Total Fat (g/100g) & 4.71 & $\begin{array}{l}\text { (2012) AOAC Official Methods. } 19^{\text {th }} \\
\text { Edtn, Vol- II, } 963.15\end{array}$ & Chakraborty et al. [9] \\
\hline Energy $(\mathrm{kJ} / 100 \mathrm{~g})$ & 1609.26 & $\begin{array}{l}\text { Composition \& Analysis of Food by } \\
\text { Pearson }\end{array}$ & Fssai [7] \\
\hline Total ash (g / $100 \mathrm{~g})$ & 4.96 & IS: 1158: 1973 (RA-2010) & Fssai [7] \\
\hline TVBN (mg/100g) & Below Detection Limit (5.0) & Fssai Lab Manual 6: 2015, Cl.no. 1.3 & Idakwo et. al [2] \\
\hline Histamine $(\mathrm{mg} / 100 \mathrm{~g})$ & 5 & Fssai Lab Manual 6, 2015 & Sen DP [1] \\
\hline$\omega-3$ fatty acids (g / $100 \mathrm{~g}$ ) & 2.2 & $\begin{array}{c}\text { AOAC Official Method19 } 9^{\text {th }} \text { Edition } \\
\text { Vol- II, } 996.06\end{array}$ & Kris E [10] \\
\hline Mercury (Hg) (mg / kg) & Below Detection Limit (0.01) & $\begin{array}{c}\text { AOAC Official Methods. } 19^{\text {th }} \text { Edition, } \\
\text { 2012; Vol- I, } 971.21\end{array}$ & Torres E [11] \\
\hline
\end{tabular}

\section{RESULTS AND DISCUSSION}

For vacuum drying with silver-plate heater, Linear Model was found as the best drying model. At three pre-set temperatures (40 ${ }^{\circ} \mathrm{C}, 45{ }^{\circ} \mathrm{C}$ and $50{ }^{\circ} \mathrm{C}$ ), the $\mathrm{D}_{\text {eff }}$ was found to remain within the range of $3.945 \times 10^{-10}$ to $7.366 \times 10^{-9} \mathrm{~m}^{2} / \mathrm{s}$. The activation energy, E, was found to be $33.20 \mathrm{~kJ} /$ mole that signifies ease of moisture removal.

Moisture and $\mathrm{pH}$ of blended material before VD were found $64.97 \%$, and 5.90 respectively. The same for final dried product were $3.06 \%$ and 6.53 respectively. So, the final product produced was a least moisture content alkaline product. The water activity $\left(a_{w}\right)$ value was found 0.212 . Very minimum $a_{w}$ value for the final product suggests that it has better shelf life and stability.

VD time was found $2.55 \mathrm{~h}$ for Ag plate heater. The total carbohydrate, protein, total fat, energy and total ash are found as $34.99 \mathrm{~g} / 100 \mathrm{~g}, 50.66 \mathrm{~g} / 100 \mathrm{~g}, 4.71 \mathrm{~g} / 100 \mathrm{~g}, 1609.26 \mathrm{~kJ} / 100 \mathrm{~g}$, and $4.96 \mathrm{~g} / 100 \mathrm{~g}$ respectively. Also, histamine and $\omega-3$ fatty acids were analyzed $5 \mathrm{mg} / 100 \mathrm{~g}$ and $2.2 \mathrm{~g} / 100 \mathrm{~g}$ respectively. Both TVBN (< $5 \mathrm{mg} / 100 \mathrm{~g})$ and mercury $(<0.01 \mathrm{mg} / \mathrm{kg})$ of final VD sample were found below detection limit.

In the sensory analysis, the average scores were obtained from the scores of twenty-two tasters as: appearance (8.10), color (8.33), flavor (8.05), taste (8.05), texture (8.40) and overall acceptability (8.25).

\section{CONCLUSION}

Successive blending of fishes and Shrimp, flours, aloe vera and kiwi fruit pulp coupled with vacuum drying could produce a good quality fortified food with low moisture (water activity), high protein, good quality fats content (with low histamine, TVBN and mercury level) to overcome malnutrition and increase the immunity system of ourselves (important with respect to current scenario) for both developing and developed countries. The food processing protocols developed here will encourage thinking in new directions to get fortified food which contain required macro and micronutrients in a single product.

\section{REFERENCES}

1. DP Sen (2005) Advances in fish processing technology (2005) Allied Publishers Private Limited, New Delhi, India.

2. Idakwo YP, Negbenebor AC, Badau HM, Gbenyl ID (2016) Total volatile base nitrogen (TVBN) and trimethylamine (TMA) content of "Bunyi youri" as influenced by the addition of glucose and clove during storage. International Journal of Biotechnology 4(5): 81-85.

3. Vanitha M (2011) Development of value-added products from Catla (Catla catla) and its quality evaluation. Department of fish processing technology. College of Fishery Science. Sri Venkateswara Veterinary University, Andhra Pradesh, India.

4. Mohanty BP, Ganguly S, Sridhar N (2016) DHA and EPA content and fatty acid profile of 39 Food Fishes from India. Biomedical Research International 2016: 4027437.

5. Jessica RB, Shakuntala HT, Geoffrey C, Md Abdul Waheb, Mostafa AR, et al. (2015) Nutrient composition of important fish species in Bangladesh and potential contribution to recommended nutrient intakes. Journal of Food Composition and Analysis. ELSEVIER 42: 120-133.

6. Doe PE, Olley J (1990) Drying and dried fish products in sea food resources, national composition and preservation. In Zdzislavia E (Edn), Boca Raton FL CRC press, 270.

7. Food Safety and Standards Authority of India - FSSAI. (2010). Training manual for food safety regulators. Food Safety and Standards Act, 2006 (Vol. 1 - Introduction to food and food processing). 
8. Maskan M (2001) Drying, shrinkage and rehydration characteristics of kiwi fruits during hot air and microwave drying. Elsevier Journal of Food Engineering 48(2): 177-182.

9. Chakraborty R, Mukhopadhyay P, Bera M, Suman S (2011) Infraredassisted freeze-drying of tiger prawn: parameter optimization and quality assessment. Journal of Drying Technology 29: 508-519.

10. Kris-Etherton PM, Harris WS, Appel LJ (2002) Fish consumption, Fish oil, Omega-3 fatty acids and Cardiovascular disease. Journal of American Heart Association 106: 2747-2757.
11. Torres-Escribano S, Velez D, Montoro R (2010) Mercury and methylmercury bio accessibility in swordfish. Journal of Food Additives \& Contaminants. 27 (3): 327-37.

12. Chakraborty N, Chakraborty R, Saha AK (2020) Fortified and freezedried kiwi fruit (Actinidia deliciosa): quality and sensory assessment. Brazilian Journal of Food Technology 23: e2019077. 